\title{
Parameters Influencing Haematological, Serum and Bio-Chemical References in Livestock Animals under Different Management Systems
}

\author{
Gbolabo O. Onasanya ${ }^{1 *}$, Florence 0. Oke1, Timothy M. Sanni' ${ }^{2}$ Aliyu I. Muhammad ${ }^{1}$ \\ ${ }^{1}$ Department of Animal Science, Federal University, Dutse, Nigeria \\ ${ }^{2}$ Department of Animal Breeding and Genetics, Federal University of Agriculture, Abeokuta, Nigeria \\ Email: ${ }^{*}$ onasanya.gbolabo@gmail.com
}

Received 10 February 2015; accepted 25 August 2015; published 28 August 2015

Copyright (C) 2015 by authors and Scientific Research Publishing Inc.

This work is licensed under the Creative Commons Attribution International License (CC BY). http://creativecommons.org/licenses/by/4.0/

(c) (i) Open Access

\section{Abstract}

Serum bio-chemical and haematological indices constitute important panels in the diagnosis, prognosis and treatment of livestock diseases via the investigations of myriads of parameters influencing these blood and serum bio-chemical indices. Serum bio-chemical indices, haematological indices and blood electrolytes are critical physiological indices which have health implications on the diagnosis, prognosis and treatment of livestock diseases especially in animals bred under different management systems. It is important to stress that cascades of parameters of both genetic and non-genetic origin greatly have direct and in-direct health implications on serum biochemical indices and blood electrolytes in livestock animals and subsequently on their health/ production performances. Laboratory blood tests would be a vital tool to help detect any deviation from normal state of wellbeing in animals. Therefore, this review intends to provide base line information to establish certain haematological and serum bio-chemical indices as standard references which can be employed as alternative therapy for diagnosis, prognosis and treatment of cascades of diseases plaguing livestock animals bred under different management systems especially under the harsh condition of the tropics. Hence, it is important to establish standard values for the various blood and serum bio-chemical indices base on parameters of non-genetic origin; age, sex, physiological state, stress level, management systems, medication, health status, nutrition, hormone, climate, etc. and genetic parameters which include the breed and genotype of the animal among others obviously affect the blood and serum profile of healthy animal which subsequently influence their production performance and efficiency.

\footnotetext{
${ }^{*}$ Corresponding author.
} 
Keywords

\author{
Haematological Indices, Serum Bio-Chemical Indices, Diagnosis, Blood Electrolytes, Physiological \\ Indices
}

\title{
1. Introduction
}

Serum bio-chemical and haematological references constitute important panels in the diagnosis, prognosis and treatment of livestock diseases via the investigations of myriads of parameters influencing blood and serum biochemical indices among which are packed cell volume (PCV), mean corpuscular volume (MCV), total blood glucose (TBG), total protein (TP), urea, creatinine, uric acid, alanine aminotransferase or alanine transaminase (ALT), aspartate aminotransferase (AST), alkaline phosphatase (ALP), lactate dehydrogenase (LDH), creatinine kinase (CK), albumin (Alb), c-glutamyl transpeptidase (GGT), amylase, globulin, cholesterol, very low density lipoprotein (VLDL), triglyceride, folate, vitamin $A$ and $E$, triiodothyronine $\left(T_{3}\right)$, thyroxine $\left(T_{4}\right)$, free triiodothyronine $\left(\mathrm{fT}_{3}\right)$ and free thyroxine $\left(\mathrm{fT}_{4}\right)$ concentrations, serum retinol and $\alpha$-tocopherol concentration in livestock animals [1]. The following parameters namely: species, breed, sex, age, malnutrition, illness, reproductive status, season, nutrition and management systems etc. can affect serum biochemistry of livestock animals [2] [3].

The parameters influencing the haematology and serum bio-chemistry of various livestock animals are typically under two broad categories e.g. genetic and non-genetic parameters. Genetic parameters include the breed and genotype of the animal while the non-genetic parameters include the age, sex, management system, medication, health status and environmental factors such as nutrition, hormone and climate. Haematological values of farm animals are also influenced by geographical location, season, climate, day length, time of day, life habit of species, nutritional status, physiological status of individual animal and other non-genetic factors [4] [5]. Laboratory blood tests would be a vital tool to help detect any deviation from normal state of wellbeing of animals [6] [7]. Hence, it is important to establish standard values for the various blood parameters based on age aforementioned genetic and non-genetic parameters.

\section{Effects of Diet/Nutrition and Management Systems on Serum Biochemistry}

Haematology and serum biochemistry assay of livestock determine the physiological disposition of the animals to their nutrition [7] [8]. The serum vitamin, protein and lipid concentrations are affected by diet/nutrition [2]. It was reported that Omani goats reared under intensive system with commercial feeds had higher levels of serum vitamin $B_{12}$ relative to their counterpart reared under extensive system with greens and forages [9]. Deficiency of both macro and micro-nutrients elicit humongous variation in haematological and serum biochemistry of livestock animals. For instance, trace element cobalt has been found to play a very significant role in the biosynthesis of vitamin $B_{12}$ in livestock animals. Therefore, deficiency of cobalt in animal feeds could lead to vitamin $B_{12}$ deficiencies related diseases, for example liver related disease called hepatic lipidosis. For example, animals reared under extensive systems tend to have lower glucose levels compared to those reared under intensive systems. The sedentary nature of the animals under intensive care may probably cause the increase levels of blood glucose while the animals under extensive care might have consumed appreciable levels of their blood glucose for physical and ranging activities. Therefore, the management system under which animals are kept greatly affect a wide range of haematological and serum biochemical parameters.

\section{The Effect of Seasonal, Physiological and Hormonal Variations on the Serum Bio-Chemistry}

Haematological constituents reflect the physiological responsiveness of the animal to its internal and external environments [10]. Season was found to have a pronounced effect on ALP levels with higher values during short-rainy and after long rainy seasons in Arsi-Bale, central highland goats and long-eared Somali goats relative to dry season [11]. The seasonal changes markedly influenced the activity of ALP levels with higher values during winter relative to other seasons of the year. Similarly, activities of AST/GOT and ALT/GPT were higher during the summer compared to other seasons of the year. The season of the year largely affect ALP in the three 
indigenous goat breeds with consistently higher values after long-rainy season as compared to other seasons in all other breeds studied [11]. The hormones, especially thyroid hormones largely influence the whole metabolism and play a significant role in the reproductive cycle of ewes. There is the possibility of thyroid hormones affecting serum chemistry just like it does to all other systems in the body [12] [13]. Reported changes in concentrations of thyroid hormones due to the effect of season affected the functional mechanisms of this biochemical index [3] [14]-[18]. According to [19], the influence of reproductive status of animals affects thyroid hormonal activities and consequently metabolic activities of the animal. Investigations related to the effect of the seasonal variations on serum bio-chemistry revealed that Vit-E levels in sheep decline during winter [20] [21]. Also, the effect of reproductive status on the Vit-E levels in pigs has been documented to have exaggerated declined during lactation periods relative to Vit-E levels obtained during the period of pregnancy [22]. Studies conducted on sheep alludes the reason for the greater decline in Vit-E levels during lactation to pregnancy to increase requirement of Vit-E for lamb development, increase demand for this serum bio-chemical index (Vit-E), provokes the more Vit-E transport to the lamb via mother's milk than to the fetus via the placenta [1]. In addition, serum Vit-A concentrations slightly decreased during pregnancy and this could be due to increase requirements for the Vit-A as a result of Vit-A transport from the ewe to the foetus via the placenta [1].

It was noted that Vit-A and $\mathrm{E}$ deficiencies are associated with higher lamb mortality and lower total body weight of lambs [22]. Therefore, it is advisable that sheep should be given Vit-E and Vit-A supplements during pregnancy and lactation periods mitigate these sub-clinical challenges. In pregnant ewe, the values of $T_{4}$ in cold seasons (October and January) were higher than $\mathrm{T}_{4}$ values recorded in hot seasons (April and July) [1]. Seasonal variations also affect $T_{4}$ values in sheep [3] [14] [15], in calves [16], in goats [17] [18]. This might informs that cold environment could be a stimulus that increases the levels of thyrotrophic hormone, thereby resulting in higher concentrations of thyroid hormones in serum. Conversely, in non-pregnant ewe it was reported that the $\mathrm{T}_{4}$ values obtained in cold seasons were lower than those values obtained in hot seasons [23]. The reason for the different levels of $\mathrm{T}_{4}$ obtained in the output of thyrotrophic hormone in both cold and hot seasons could probably be alluded to the increased thyroid binding protein (TBP) synthesis which was due to the elevated estradiol levels in pregnant ewe rather than non-pregnant ewe [1]. Increase concentration of serum $\mathrm{T}_{3}$ levels was also observed in Indian sheep examined under summer season [24]. Sheep are season dependent polyestric animals, as a result of this, their serum estradiol levels increases during autumn and winter, even if they are found pregnant or not. Thus, it is not unexpected that $\mathrm{T}_{4}$ levels is higher than $\mathrm{T}_{3}$ levels, this higher levels is due to increase TBP synthesis which causes elevated $\mathrm{T}_{4}$ levels rather than $\mathrm{T}_{3}$ levels [25] [26]. Physiological status was examined on serum bio-chemistry in cows [27], cats [28] and mares [29] where a decreased triglyceride, cholesterol and VLDL levels in both pregnant and non-pregnant ewe were documented [1] [3]. Physiological status is also associated with a strong reduction in lipogenesis during the pregnancy and lactation periods [1] [3]. All through pregnancy and lactation periods the number of total insulin receptors (TIR) decreases and insulin stimulation of lipogenesis becomes in-efficient [19] [30]. A decreased triglyceride levels in pregnant ewe and non-pregnant counterparts could be related to the increase in insulin resistance. Another reason for the low levels of triglyceride, cholesterol and VLDL in both pregnant and non-pregnant ewe could also be dependent on consistent seasonal variations but not with reproductive status [1]. Also, creatinine and uric acid concentration varied with seasonal variations but not with reproductive status [1]. Decreased urea/creatinine and albumin/globulin ratios and increased albumin and creatinine levels also low protein uptake and dehydration have been related to seasonal variation due to fluid loss [1].

In addition, the elevated urea/creatinine ratio is important indicator of the increased GFR which increases especially in late gestation due to the increased total blood volume. The reason for the higher urea/creatinine ratio in pregnant ewe relative to non-pregnant counterparts could be due to the increase in GFR and reproductive status of sheep [31]. Serum glucose levels showed no reproductive and seasonal rhythm in sheep, the reason for maintaining constant glucose concentration in ewe might be depended on the different carbohydrate metabolism rather than season, while ALP activities increased in late pregnancy in ewe [1]. The amylase activities in mated ewe were higher than the non-mated ewe. ALT activities were also reported to be affected only by reproductive status in sheep and goat [1]. Furthermore, total protein (TP), globulin, cholesterol, creatinine, uric acid and $\mathrm{T}_{4} / \mathrm{T}_{3}$ ratio varies with seasonal variations while the concentrations of ALT, $T_{4}, f T_{4}$ in serum varies only with reproductive status. However, urea, LDH, CK, aspartate AST, ALP, Alb, Amylase, TBG, VLDL, Vit A-E, $\mathrm{T}_{3}$ and $\mathrm{fT}_{3}$ concentration vary with both seasonal variations and reproductive status of the animals. Neither the season nor the reproductive status effected folate, glucose and GGT values in both pregnant and non-pregnant groups of the 
sheep. However, the least Vit-E concentration was reported during lactation periods. Moreover, folate, GGT, TBG, globulin, TP, creatinine, uric acid, cholesterol, and $\mathrm{T}_{4} / \mathrm{T}_{3}$ ratio could be used as reference parameters in both mated and non-mated ewe basically because no differences were found due to the reproductive status [1].

\section{Effect of Insect Infestation on Haematological and the Serum Bio-Chemistry}

Significant proportion of the available information on the haematology and biochemistry for livestock in the humid tropics has mostly been on disease prognosis [32]. The disruption of erythrocyte membrane integrity has been reported to be caused directly or indirectly by the trypanosomes or their secreted products [32] [33]. Significant reduction in erythrocyte membrane sialoglycoproteins due to increased activity of circulating neuraminidases (sialidases) provoked by trypanosomes has also been reported to play a significant role in the development of anaemia in African animal trypanosomosis [33]. These phenomena have been reported to be responsible for early sequestration and destruction of erythrocytes by cells of the mononuclear phagocytic series and subsequent anaemia during trypanosomosis. Erythrocyte peroxidation is one of the factors that have been observed to play an important role in the pathogenesis of anaemia in acute trypanosomosis in experimental mice infected with T. brucei. Trypanosomes and activated phagocytes (macrophages and neutrophils) are known to elaborate sialidases, proteases, reactive oxygen radicals such as $\mathrm{O}_{2}, \mathrm{OH}$ leading to the rapid destruction erythrocyte membranes during infection [33].

\section{The Influence of Stress on Physiological, Haematological and Clinical Blood Chemistry}

Stress is described as a factor that elicits defense mechanisms in animals [34]. Therefore, a stress stimulus (stresssor) is any situation that stimulates defense responses in animals. Combination of conditions in which the animal lives may act as stressors. In mammals, respiration is the direct expulsion of carbon dioxide from tissues of the body and elimination of moisture from respiratory tract to help prevent hyperthermia under high ambient temperatures, which is a major adaptive feature of domestic livestock in the hot tropical Africa. The rate of respiration was found to be largely affected by pathogenic $T$. vivax [35]. The reduction in the respiratory rate of goats infected with pathogenic T. vivax indicates that the infected animals may be more stressed than their non-infected counterpart. This is an indication that pathogenic $T$. vivax could be referred to as stressor in goats and the measurement of respiratory rate is an indication of the physiological alterations of stressed and infected animals as caused by T. vivax [35]. Thermal stressor as a form of environmental heat stress negatively influenced livestock physiological activities especially when an animal is having difficulty in dissipating excess heat load to its environment which subsequently frustrate overall performance e.g. growth, feed intake, lactation, conception, gestation etc. [36]. Handling, temperature variation, injections, fear, changes in the social hierarchy, fight, noise and associated factors may provoke a state of stress in livestock animals. The response characterized by fight or flight, usually result to a manifestation of immediate increases in blood pressure, respiration rate, pulse rate, muscle tone, nerve sensibility and blood sugar. Stressful situations or adrenocorticotropic hormone injection leads to a change in the heterophil/lymphocyte $(\mathrm{H} / \mathrm{L})$ ratio. $\mathrm{H} / \mathrm{L}$ ratio has been accepted as a good measure of a chicken's perception of stress in its environment [37] [38]. Series of stressors were believed to produce a stereotyped response that has been formulated as the "general adaptation syndrome" that can be divided into three stages namely alarm, adaptation, and exhaustion. However, it has been shown that some stimuli differ in the response they evoke [34]. Captive ibex had higher hematocrit values, hemoglobin concentration and higher erythrocyte counts than the same animals when captured [39], these increases could be due to the effect of stress load on these parameters [40].

Also, differences in red blood cell (RBC) counts may be attributable to stress (splenic contraction), hydration status, hormonal influences, dietary/nutritional differences, adaptations to a desert environment or adaptation to a high mountain environment [41]. Epinephrine release could be due to handling and transport stress, capture, as well as disease and allergic reactions [41] [42]. Stress can be imposed on animals during transportation for short or long periods [43]. Several authors have reported that transportation induces changes in the blood composition of food animals as well as other body parameters like heart rate, electrolytes, enzymes, hormones, metabolites, live weight and meat quality [44] [45]. It was reported in a study conducted on rabbits, that haematological parameters was significantly influenced by transport of rabbits to the abattoir thus haematological parameters could be employed to highlight the stress condition of rabbits during transport [45]. Decrease in stress has been 
documented as one of the factors influencing heterophils and lymphocytes levels in animals [34]. In clinical chemistry, increase of glucose and creatine kinase and a decrease of uric acid were observed. In addition, there was a decrease in the total white blood, basophils and lactate dehydrogenase [34]. Conversely, monocytes, eosinophils, aspartate aminotransferase, total protein, and the packed cell volume are not influenced by stress [34]. Young animals have relatively high levels of creatinine kinase which may be linked with susceptibility to stress-induced events such as capture and handling and capture myopathy [42]. Stress could affect transaminases activity in livestock animals [46]-[49], severe exercises (stressor) were reported to have resulted in an increase in these enzymes e.g. ALP and AST [50]. Therefore, abrupt or sudden stress induction could elicit enough changes in enzymatic activity owing to increased stimulation by corticoids.

\section{Effect of Age on Haematological, Blood Electrolytes and Serum Biochemical Indices}

As the age of the ewes increase there is slight increase in the concentrations of globulin and total protein and decreases in the concentrations of calcium, phosphorus, creatinine, TBG, albumin, activities of alkaline phosphatase and glutathione peroxidase. The concentration of calcium was low in the four or more year old group of ewes and the concentration phosphorus was also markedly low in the two to three years old and four or more years old groups of ewes examined [51]. Lower concentrations of phosphorus in ewes between two-and-half and three and half years old but no differences in calcium concentration in ewes over one-and-a-half years old [52]. Phosphorus concentration has been found to decrease with age in ruminant. This could possibly be due to reduction in its absorption from the gut [53]. Total protein concentration was recorded to be slightly higher in older ewes which were attributed to a possible increase in globulin and a slight decrease in albumin [54]. Similarly, the reduction in albumin and the increase in globulin concentrations is proportional to increase in age and these have been associated with a reduction in protein synthesis (albumin) by the liver and an increased exposure to different antigens and/or diseases over time, hence stimulating more antibodies (globulins) into the blood stream to fight these antigens and/or diseases [51]. The lower glucose concentrations documented in mature ewes could be associated with a lower rate of recovery of glucose [53]. In terms of age, alkaline phosphatase decreased successively with the increasing age of animals [51]. Also, a decrease in the renal clearance of creatinine has been linked to age [55]. Activities of gamma-glutamyl transferase, aspartate aminotransferase, alanine aminotransferase, creatinine phosphokinase were not affected by increase in age, whereas activities of glutathione peroxidase decrease with increase in age [51].

Younger animals are more vulnerable to vitamin $\mathrm{B}_{12}$ deficiencies relative to adult animals. Therefore, they are more prone to vitamin $B_{12}$ deficiencies related diseases e.g. hepatic lipidosis than their adult counterparts [9]. Omani kids recorded lower vitamin $\mathrm{B}_{12}$ levels than older goat and they are consequently prone to hepatic lipidosis [9]. Mean corpuscular volume, haemoglobin concentration, and mean corpuscular haemoglobin concentration increase with age and leukocytes counts and lymphocytes counts decreased in animals from 3 - 10 years of age [39] [56]. Young animals have lower total protein concentrations [42] and this informs the supplementation of protein into the diet of young animals. Alkaline phosphatase levels are higher in young animals because of bone growth [42]. Higher ALP values were recorded for Arsi-bale goats of age groups 6 - 12 months and 12 - 24 months and 12 - 24 months for central highland goats. Higher ALP levels were also documented in adults goat compared to kids [57] [58]. These age-related changes have also been reported for other wild ungulates such as bighorn sheep [41]. Most enzymatic systems varies with age and that there is higher serum ALT/GPT levels in goats between 12 - 24 months old and adults older than 24 months relative to goats younger than 12 months and this could be associated with specific physiological factors such as increased muscular activity of goats during puberty [46]. It was reported in a study conducted on indigenous chickens that age group affect packed cell volume, red blood cell and white blood cell [59]. The majority of haematological parameters increase with advancing age of the indigenous chickens [59].

\section{Influence of Sex on Haematological and the Serum Biochemistry}

Male indigenous chickens generally have higher mean values in the majority of haemotological parameters estimated compared to their female counterparts across all genotypes studied [59] [60]. Male recorded higher mean corpuscular volume than the values recorded in females [59]. The effect of sex was evidently observed in Haemoglobin concentration, females having higher mean corpuscular haemoglobin concentration values relative 
to males. The sex evidently influenced lymphocyte and neutrophils in West African Dwarf (WAD) goat, where male WAD goats had increased lymphocyte values compared to their female counterparts [58]. Creatinine kinase values were evident in females than males. Total protein levels were markedly higher in males than female animals. Creatinine is produced in active buck's muscle tissue. Its production is directly related to buck's the muscular mass. Higher ALP values were documented in male Ibex [39]. Sex had evidently influence ALT/GPT with higher values recorded for females than males. Another possible explanation for sex differences in blood and serum bio-chemistry is the adrenal cortex, since there is a sex difference in adrenal function which is dependent on ovarian activity [47].

\section{Conclusion}

Haematological, blood electrolytes and serum bio-chemical reference are alternative, dependable and reliable panel to diagnosis and prognosis of animal disease, infection and animal health status as changes in these parameters are indicators of pathophysiological responses thus providing a base line information on the epidemiology of livestock animals towards attenuating economic loss, improving management practices, evaluation of nutrition and improving health management practices.

\section{References}

[1] Yokus, B., Cakir, D.U., Kanay, Z., Gulten, T. and Uysal, E. (2006) Effects of Seasonal and Physiological Variations on the Serum Chemistry, Vitamins and Thyroid Hormone Concentrations in Sheep. Journal of Veterinary Medicine, 53, 271-276. http://dx.doi.org/10.1111/j.1439-0442.2006.00831.x

[2] Swanson, K.S., Kuzmuk, K.N., Schook, L.B. and Fahey, G.C. (2004) Diet Affects Nutrient Digestibility, Hematology, and Serum Chemistry of Senior and Weanling Dogs. Journal of Animal Science, 82, 1713-1724.

[3] Nazifi, S., Saeb, M., Rowghani, E. and Kaveh, K. (2003) The Influences of Thermal Stress on Serum Biochemical Parameters of Iranian Fat-Tailed and Their Correlation with Triiodothyronine, Thyroxine and Cortisol Concentrations. Comparative Clinical Pathology, 12, 135-139. http://dx.doi.org/10.1007/s00580-003-0487-x

[4] Afolabi, K.D., Akinsoyinu, A.O., Olajide, R. and Akinleye, S.B. (2010) Haematological Parameters of the Nigerian Local Grower Chickens Fed Varying Dietary Levels of Palm Kernel Cake. Proceedings of 35th Annual Conference of Nigerian Society for Animal Production, Ibadan, 14-17 March 2010, 247.

[5] Etim, N.N., Williams, M.E., Akpabio, U. and Offiong, E.E.A. (2014) Haematological Parameters and Factors Affecting Their Values. Agricultural Science, 2, 37-47. http://dx.doi.org/10.12735/as.v2i1p37

[6] Ogunbajo, S.O., Alemede, I.C., Adama, J.Y. and Abdullahi, J. (2009) Haematological Parameters of Savannah Brown Does Fed Varying Dietary Levels of Flamboyant Tree Seed Meal. Proceedings of 34th Annual Conference of Nigerian Society for Animal Production, Philadelphia, 15-18 March 2009, 88-91.

[7] Menon, D.G., Bennett, D.C. Schaefer, A.M. and Cheng, K.M (2013) Hematological and Serum Biochemical Profile of Farm Emus (Dromaius novaehollandiae) at the Onset of Their Breeding Season. Poultry Science, 92, 935-944. http://dx.doi.org/10.3382/ps.2012-02870

[8] Madubuike, F.N. and Ekenyem, B.U. (2006) Haematology and Serum Biochemistry Characteristics of Broiler Chicks Fed Varying Dietary Levels of Ipomoea asarifolia Leaf Meal. International Journal of Poultry Science, 5, 9-12. http://dx.doi.org/10.3923/ijps.2006.9.12

[9] Al-Zadjali, A., Johnson, E.H. and Srikandakumar, A. (2004) Serum Vitamin $B_{12}$ in Omani Goats. Tropical Animal Health and production, 36, 473-482. http://dx.doi.org/10.1023/B:TROP.0000035009.66980.2b

[10] Esonu, B.O., Emenalom, O.O., Udedibie, A.B.I., Herbert, U. Ekpor, C.F., Okolie, I.C. and Iheukwumere, F.C. (2001) Performance and Blood Chemistry of Weaner Pigs Fed Raw Mucuna (Velvet Bean). Tropical Animal Production Investigations, 4, 49-54.

[11] Hussain, S.O., Al-Janabi, A.S., Asofi, M.K. and Al-Badry, K.L. (2003) Seasonal Changes in Serum Enzymes of Male Goats. Iraqi Journal of Veterinary Science, 17, 1-5.

[12] Webster, J.R., Moenter, S.M., Woodfill, C.J. and Karsch, F.J. (1991) Role of the Thyroid Gland in Seasonal Reproduction. II. Thyroxine a Season-Specific Suppression of Gonadotropin Secretion in Sheep. Endocrinology, 129, 176-183. http://dx.doi.org/10.1210/endo-129-1-176

[13] Karsch, F.J., Dahl, G.E., Hachigian, T.M. and Thrun, L.A. (1995) Involvement of Thyroid Hormones in Seasonal Reproduction. Journal of Reproductive Fertility, 49, 409-422.

[14] Salem, M.H., El-Sherbiny, A.A., Khalil, M.H. and Yousef, M.K. (1991) Diurnal and Seasonal Rhythm in Plasma Cortisol, Triiodothyronine, Thyroxine as Affected by the Wool Coat in Barki Sheep. Indian Journal of Animal Sciences, 
61, 946-951.

[15] Buys, N., Peeters, R., De Clerck, B., Van Isterdael, J., Kuhn, E.R. and Decuypere, E. (1990) Seasonal Variations in Prolactin, Growth Hormone and Thyroid Hormones and the Prolactin Surge at Ovulation Do Not Affect Litter Size of Ewes during Pregnancy in the Oestrous or the Anoestrous Season. Journal of Reproductive Fertility, 90, 47-53. http://dx.doi.org/10.1530/jrf.0.0900047

[16] Baccari Jr., F., Johnson, H.D. and Hahn, G.L. (1983) Environmental Heat Effects on Growth, Plasma T 3 , and Post-Heat Compensatory Effects on Holstein Calves. Proceedings of the Society for Experimental Biology and Medicine, 173, 312-318. http://dx.doi.org/10.3181/00379727-173-41648

[17] Prakash, R. and Rathore, R. (1991) Seasonal Variations in Blood Serum Profiles of Triiodothyronine and Thyroxine in Goat. Indian Journal of Animal Sciences, 61, 1311-1312.

[18] Abdel-Same, A.M. (1996) Heat Adaptability of Growing Bedouin Goats in Egypt. Tropenlandwirt, 97, 137-147.

[19] Burtis, C.A. and Ashwood, E.R. (1999) Tietz Textbook of Clinical Chemistry. 3rd Edition, W. B. Saunders Co., Philadelphia, 29-150.

[20] Asadian, A., Mirhadi, S.A. and Mezes, M. (1995) Seasonal Variation in the Concentration of Vitamins A and E in the Blood Plasma of Fat Tailed Sheep. Acta Veterinaria Hungarica, 43, 453-461.

[21] Hidiroglou, M. and Williams, C.J. (1986) Interrelationships among Liposoluble Vitamins in Ruminants. American Journal of Veterinary Research, 47, 1767-1771.

[22] Vrzgula, L., Kovac, G. and Prosbova, M. (1979) Vitamin E Concentration in the Blood Serum of Sows during Pregnancy and Lactation. Veterinarni Medicina, 24, 403-408.

[23] Berthon, D., Herpin, P., Le Dividich, J., Dauncey, M.J. and Le-Dividich, J. (1996) Interactive Effects of Thermal Environment and Energy Intake on Thyroid Hormone Metabolism in Newborn Pigs. Biology of the Neonate, 69, 51-59. http://dx.doi.org/10.1159/000244278

[24] Ashutosh, O.P., Dhandan, O.P. and Kundu, R.L. (2001) Effect of Climate on the Seasonal Endocrine Profile of Native and Crossbred Sheep under Semi-Arid Conditions. Tropical Animal Health Production, 33, 241-252.

http://dx.doi.org/10.1023/A:1010318922445

[25] Camacho, G.R., Ceballos, L.T., Angelin, P.B., Moreno, J.A., Nieto, L.M. and Gonzalez, G.J. (2003) Renal Failure and Acquired Hypothyroidism. Pediatric Nephrology, 18, 290-292.

[26] Foester, J. (1993) Heamotogic Diseases of the New Born. Wintrobe’s Clinical Haematology, 9th Edition, Vol. 1, 1151-1169.

[27] Marcos, E., Mazur, A., Cardot, P. and Rayssiguier, Y. (1990) The Effect of Pregnancy and Lactation on Serum Lipid and Apolipoprotein B and A-I Levels in Dairy Cows. Journal of Animal Physiology and Animal Nutrition, 64, 133-138. http://dx.doi.org/10.1111/j.1439-0396.1990.tb00214.x

[28] Watson, T.D., Butterwick, G.R., McConnell, F.M. and Markwell, P.J. (1995) Development of Methods for Analyzing Plasmalipoprotein Concentrations and Associated Enzyme Activities and Their Use to Measure the Effects of Pregnancy and Lactation in Cats. American Journal of Veterinary Research, 56, 289-296.

[29] Watson, T.D., Burns, G., Packard, G. and Shepherd, J. (1993) Effect of Pregnancy and Lactation on Plasma Lipid and Lipoprotein Concentrations, Lipoprotein Composition and Post-Heparin Lipase Activities in Shetland Pony Mares. Journal of Reproduction and Fertility, 97, 563-568. http://dx.doi.org/10.1530/jrf.0.0970563

[30] Guesnet, P.M., Massoud, M.J. and Demarne, Y. (1991) Regulation of Adipose Tissue Metabolism during Pregnancy and Lactation in the Ewe: The Role of Insulin. Journal of Animal Science, 69, 2057-2065.

[31] Fischbach, F.A. (2000) Manual of Laboratory and Diagnostic Tests. 6th Edition, Lippincott, Philadelphia, 5-155.

[32] Ikhimioya, I. and Imasuen, J.A. (2007) Blood Profile of West African Dwarf Goats Fed Panicum maximum Supplemented with Afzelia africana and Newbouldia laevis. Pakistan Journal of Nutrition, 6, 79-84. http://dx.doi.org/10.3923/pjn.2007.79.84

[33] Taiwo, V.O., Olaniyi, M.O. and Ogunsanmi, A.O. (2003) Comparative Plasma Biochemical Changes and Susceptibility of Erythrocytes to in Vitro Peroxidation during Experimental Trypanosoma congolense and T. brucei Infections in Sheep. Israel Journal of Veterinary Medicine, 58, 112-117.

[34] Scope, A., Filip, A.T., Gabled, C. and Resch, F. (2002) The Influence of Stress from Transport and Handling on Hematologic and Clinical Chemistry Blood Parameters of Racing Pigeons (Columba livia domestica). Avian Diseases, 46, 224-229. http://dx.doi.org/10.1637/0005-2086(2002)046[0224:TIOSFT]2.0.CO;2

[35] Sanni, T.M., Onasanya, G.O., Adefenwa, M.A., Yakubu, A., Ikeobi, C.O.N., Adebambo, O.A., Talabi, A.O., Ozoje, M.O., Wheto, M., Takeet, M.I., Peters, S.O., De Donato, M., Thomas, B.N. and Imumorin, I.G. (2013) Molecular Diagnosis of Subclinical African Trypanosoma vivax Infection and Association with Physiological Indices and Serum Metabolites in Extensively Managed Goats in the Tropics. Open Journal of Veterinary Medicine, 3, 39-45. 
http://dx.doi.org/10.4236/ojvm.2013.31007

[36] Onasanya, G.O., Sanni, T.M., Wheto, M., Adefenwa, M.A., Yakubu, A., Ikeobi, C.O.N., Adebambo, O.A., Talabi, A.O., Ozoje, M.O., Peters, S.O., Addullahi, A.A., Omifolaji, J.K. and Imumorin, I.G. (2014) Interrelationship Studies between Heat Stress Traits, Blood and Serum Bio-Chemical Indices of Extensively Managed Nigerian Sheep. Journal of Agriculture and Veterinary Science, 7, 43-46. http://dx.doi.org/10.9790/2380-071014346

[37] Wolford, J.H. and Ringer, R.K. (1983) Adrenal Weight, Adrenal Ascorbic Acid, Adrenal Cholesterol, and Differential Leukocyte Counts as Physiological Indicators of “Stressor” Agents in Laying Hens. Poultry Disease, 23, 366-385.

[38] Gros, W.B. and Siegel, H.S. (1983) Evaluation of the Heterophil/Lymphocyte Ratio as a Measure of Stress in Chickens. Avian Diseases, 27, 972-979. http://dx.doi.org/10.2307/1590198

[39] Pérez, J.M., González, F.J., Granados, J.E., Pérez, M.C., Fandos, P., Soriguer, R.C. and Serrano, E. (2003) Hematologic and Biochemical Reference Intervals for Spanish Ibex. Journal of Wildlife Diseases, 39, 209-215. http://dx.doi.org/10.7589/0090-3558-39.1.209

[40] Peinado, V.I., Zabala, J.L. and Palomeque, J. (1995) Effect of Captivity on the Blood Composition of Spanish Ibex (Capra pyrenaica hispanica). The Veterinary Record, 137, 588-591.

[41] Borjesson, D.L. Christopher, M.M. and Boyce, W.M. (2000) Biochemical and Hematologic Reference Intervals for Free-Ranging Desert Bighorn Sheep. Journal of Wildlife Diseases, 36, 294-300. http://dx.doi.org/10.7589/0090-3558-36.2.294

[42] Marco, I., Viñas, L., Velarde, R., Pastor, J. and Lavin, S. (1997) Effects of Capture and Transport on Blood Parameters In-Ranging Mouflon (Ovis ammon). Journal of Zoo and Wildlife Medicine, 28, 428-433.

[43] Liste, G., María, G.A., Garcia-Belenguer, S., Chacòn, G., Gazzola, P. and Villarroel, M. (2008) The Effect of Transport Time, Season and Position on the Truck on Stress Response in Rabbits. World Rabbit Science, 16, 229-235.

[44] Mitchell, G., Hattingh, J. and Ganhao, M. (1988) Stress in Cattle Assessed after Handling, after Transport and after Slaughter. Veterinary Record, 123, 201-205. http://dx.doi.org/10.1136/vr.123.8.201

[45] Giammarco, M., Vignola, G., Mazzone, G., Fusaro, I. and Lambertini, L. (2012) Haematological Parameters as Indicators of Transport Stress in Rabbits. Proceedings of 10th World Rabbit Congress, World Rabbit Science Association, Sharm El Sheikh, 3-6 September 2012, 1033-1037.

[46] Tibbo, M., Jibril, Y., Woldemeskel, M., Dawo, F., Aragaw, K. and Rege, J.E.O. (2008) Serum Enzymes Levels and Influencing Factors in Three Indigenous Ethiopian Goat Breed. Tropical Animal Health Production, 40, 657-666. http://dx.doi.org/10.1007/s11250-008-9145-2

[47] Critchlow, V., Liebelt, R.A., Bar-Sela, M., Mountcastle, W. and Lipscomb, H.B. (1963) Sex Difference in Resting Pituitary Adrenal Function in the Rat. American Journal of Physiology, 205, 807-815.

[48] Nichol, C.A. and Rosen, F. (1963) Advances in Enzyme Regulation. Pergamon Press, Oxford, 341.

[49] Pearl, W., Balazs, T. and Bayske, D.A. (2000) The Effect of Stress on Serum Transaminase Activity in the Rat. Life Science, 5, 67-74. http://dx.doi.org/10.1016/0024-3205(66)90188-3

[50] El-Hassanein, E.E. and Assad, F. (1996) Physical and Physiological Responses of Camels to Exercise. Veterinary Medical Journal, 44, 73-83.

[51] Dubreuil, P., Arsenault, J. and Bélanger, D. (2005) Biochemical Reference Ranges for Groups of Ewes of Different. Veterinary Record, 156, 636-638. http://dx.doi.org/10.1136/vr.156.20.636

[52] Alonso, A.J., Teresa, R.D.E., Garcia, M., Gonzalez, J.R. and Vallejo, M. (1997) The Effects of Age and Reproductive Status on Serum and Blood Parameters in Merino Breed Sheep. Journal of Veterinary Medicine, 44, 223-231. http://dx.doi.org/10.1111/j.1439-0442.1997.tb01104.x

[53] Radostits, O.M. (2000) Veterinary Medicine. A Textbook of the Diseases of Cattle, Sheep, Pigs, Goats and Horses, 9th Edition.

[54] Per, K. and Lobl, K. (1960) Chemical and Paper Electrophoretic Analysis of Normal Sheep Serum Proteins and Lipoproteins. British Veterinary Journal, 116, 167-172.

[55] Harvey, A., Johns, R., Mckusick, V.A., Owens, A.H. and Ross, R.S. (1984) The Principles and Practice of Medicine. 21st Edition, Appleton-Century-Crofts, Norwalk, 50-150.

[56] Jain, N.C. (1993) Essentials of Veterinary Hematology. Lea and Febiger, Philadelphia, 76-250.

[57] Tambuwal, F.M., Agale, B.M. and Bangana, A. (2002) Haematological and Biochemical Values of Apparently Healthy Red Sokoto Goats. Proceeding of 27th Annual Conference Nigerian Society of Animal Production (NSAP), Akure, 17-21 March 2002, 50-53.

[58] Daramola, J.O., Adeloye, A.A., Fatoba, T.A. and Soladoye, A.O. (2005) Haematological and Biochemical Parameters of West African Dwarf Goats. Livestock Research for Rural Development, 17, 95. 
[59] Addass, P.A., David, D.L., Edward, A., Zira, K.E. and Midau, A. (2012) Effect of Age, Sex and Management System on Some Haematological Parameters of Intensively and Semi-Intensively Kept Chicken in Mubi, Adamawa State, Nigeria. Iranian Journal of Applied Animal Science, 2, 277-282.

[60] Peters, S.O., Gunn, H.H., Imumorin, I.G., Agaviezor, B.O. and Ikeobi, C.O.N. (2011) Haematological Studies on Frizzled and Naked Neck Genotypes of Nigerian Native Chickens. Tropical Animal Health Production, 43, 631-638. http://dx.doi.org/10.1007/s11250-010-9743-7 